\title{
Effect of Operating Conditions on Scrap Tire Pyrolysis
}

\author{
Carla Fabiana Scatolim Rombaldo ${ }^{a}$, Antonio Carlos Luz Lisbôa ${ }^{b}$, \\ Manoel Orlando Alvarez Méndez, Aparecido dos Reis Coutinho ${ }^{\text {a* }}$ \\ ${ }^{a}$ School of Chemical Engineering, Methodist University of Piracicaba - UNIMEP, \\ SP 306, Km 1, 13450-000 Santa Bárbara d'Oeste - SP, Brazil \\ ${ }^{\mathrm{b}}$ School of Chemical Engineering, State University of Campinas - UNICAMP, \\ CP 6066, 13083-970 Campinas - SP, Brazil
}

Received: December 18, 2007; Revised: August 6, 2008

\begin{abstract}
The ever growing focus on environmental issues has raised concerns about scrap tires, whose major component - vulcanized rubber - does not degrade easily. When burned, tires release toxic gases containing substantial amounts of sulfur and ammonia in addition to other pollutants. Dumped on empty city lots, tires are also a breeding ground for mosquitoes. Many proposals have been put forward to handle the disposal of scrap tires, but none of them have proved to offer a definitive solution. The study reported here investigated the production of fuel oil and activated carbon from the pyrolysis of scrap tires. The initial mass of rubber yielded approximately $46 \%$ of oil, $40 \%$ of activated carbon and $14 \%$ of gases. The resulting activated carbon displayed a specific surface area of $200 \mathrm{~m}^{2} \cdot \mathrm{g}^{-1}$.
\end{abstract}

Keywords: scrap tire, pyrolysis, activated carbon

\section{Introduction}

About 100 million scrap tires are discarded annually in landfills, city lots, rivers and lakes in Brazil, according to Brazil's National Tire Industry Association (Associação Nacional da Indústria de Pneumáticos - ANIP). Each year, tens of thousands of new tires are manufactured in the country. In 2005, production reached 53.4 million - about 18 million for export. Production figures in the United States and Europe are even higher ${ }^{1}$. The complex composition of scrap tires hinders their recycling. A tire may be manufactured from diverse kinds of natural and synthetic rubber, including styrenebutadiene polymers ${ }^{2,3}$.

Pyrolysis of the rubber in scrap tires is one of the most reasonable alternatives in terms of environmental protection. This pyrolysis produces liquid hydrocarbons, gaseous components and a solid residue composed mostly of carbon ${ }^{4,5}$. Previous investigations have demonstrated that the oil thus produced can be used directly as fuel oil and as a raw material in petrochemical processes ${ }^{6}$. The gas can be used as fuel gas, while the carbon can be employed as carbon black in gasification processes and as a raw material for the production of activated carbon ${ }^{7,8,9}$.

The raw material most widely utilized in the production of activated carbon derives from biomass such as wood and sugarcane bagasse. Recently, investigations have focused on producing activated carbon from other sources with high carbon content such as scrap tires, thereby promoting research in the fields of new materials and the environment ${ }^{10,11}$.

The objective of this investigation was to evaluate the influence of the process parameters of scrap tire pyrolysis, an activation process, on the production of fuel oil (the liquid fraction) and activated carbon (from the solid residue).

\section{Experimental}

The raw material, rubber tires, was pyrolyzed at low pressure (vacuum) in an inert atmosphere, and the solid residue was then physically activated. The tests were conducted under different operating conditions in terms of temperature, pressure, gas flow rates and type of activating gas. The procedure is shown in Figure 1. The experimental setup consisted of a stainless steel tubular reactor, a vacuum pump, temperature and gas flow rate controllers, a condenser, and a system to capture the oil.

To identify the effect of the independent variables, three experimental designs were outlined, each with two levels of intensity $(-1,+1)$. Tables 1,2 and 3 list the investigated variables and their respective levels for each planning.

The levels were chosen based on literature data $^{3,5,6,9}$ as well as on limitations imposed by the control system.

To characterize the porosity of the activated carbons produced by pyrolysis, the liquid and gas phases were subjected to adsorption analyses. The adsorption isotherm in the gaseous phase $\left(\mathrm{N}_{2}\right.$ at $\left.77 \mathrm{~K}\right)$ was obtained using a Gas Sorption Analyzer (Quantachrome Corp., NOVA-1200). Methylene blue analyses were carried out to assess the time required to reach adsorption equilibrium.

\section{Results and Discussion}

Table 4 shows the testing conditions and the respective oil yields from the pyrolysis process. The average oil yield was $46 \%$, which is quite satisfactory considering the availability and low price of the feedstock. Table 5 presents the results of an analysis to identify statistically significant variables, based on the oil yields.

With a confidence level of $95 \%$, the results indicate that all the variables are significant, as are the interactions between temperature and pressure (13) and heating rate and pressure (23). The effect of pressure shows negative figures, for the lower the pressure the higher the oil yield. As for the other variables with positive results, the higher their values the higher the oil yields.

Table 6 shows the operating conditions and results of the steamactivated pyrolysis of the solid residue.

The average activated carbon yield was $40 \%$. The highest values of specific surface area were obtained with the highest values of the 


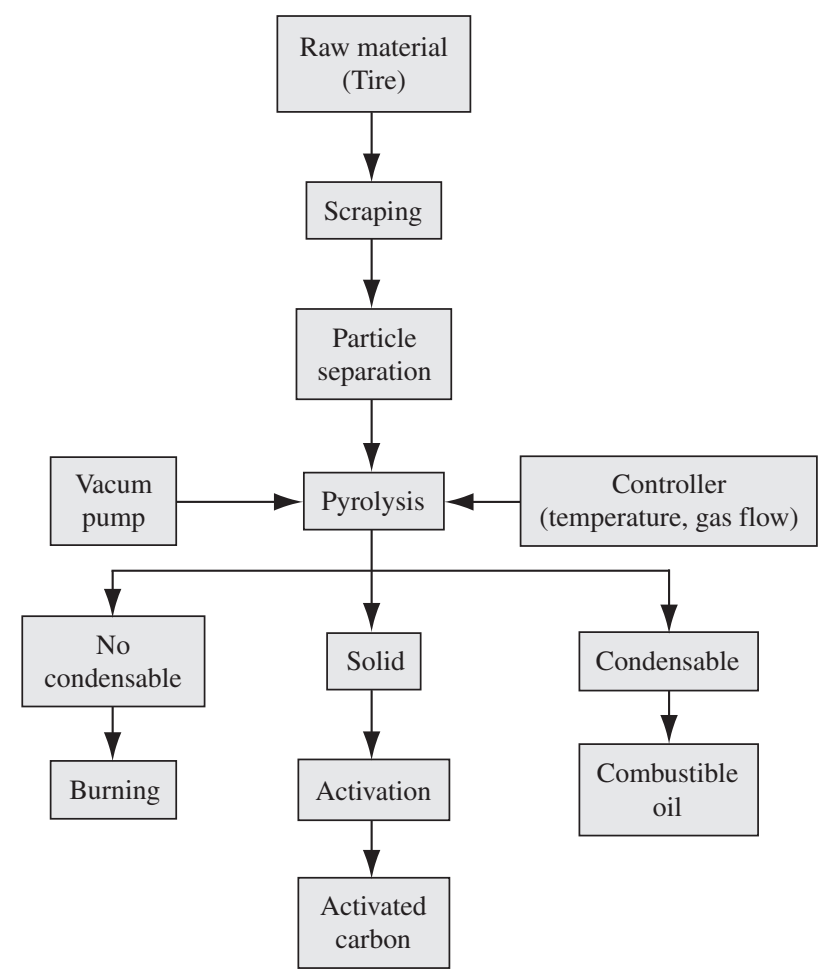

Figure 1. Block diagram of the experimental procedure.

Table 1. Variables and levels investigated for the pyrolysis process.

\begin{tabular}{lrr}
\hline \multirow{2}{*}{ Variables } & \multicolumn{2}{c}{ Levels } \\
\cline { 2 - 3 } & -1 & +1 \\
\hline Temperature $\left({ }^{\circ} \mathrm{C}\right)$ & 400 & 600 \\
Heating time $\left({ }^{\circ} \mathrm{C} / \mathrm{min}\right)$ & 3 & 8 \\
Pressure $(\mathrm{mmHg})$ & 60 & 760 \\
\hline
\end{tabular}

Table 2. Variables and levels investigated for the steam-activated process.

\begin{tabular}{lrcr}
\hline \multicolumn{1}{c}{ Variables } & \multicolumn{3}{c}{ Levels } \\
\cline { 2 - 4 } & \multicolumn{1}{c}{0} & \multicolumn{1}{c}{0} \\
\hline Temperature $\left({ }^{\circ} \mathrm{C}\right)$ & 700 & 800 & 900 \\
Activation time $(\mathrm{min})$ & 60 & 120 & 180 \\
Steam flow rate $(\mathrm{mL} / \mathrm{min})$ & 500 & 750 & 1000 \\
\hline
\end{tabular}

Table 3. Variables and levels investigated for the $\mathrm{CO}_{2}$-activated process.

\begin{tabular}{lrcr}
\hline \multirow{2}{*}{ Variables } & \multicolumn{3}{c}{ Levels } \\
\cline { 2 - 4 } & \multicolumn{1}{c}{0} & \multicolumn{1}{c}{+1} \\
\hline Temperature $\left({ }^{\circ} \mathrm{C}\right)$ & 600 & 750 & 900 \\
Heating time $\left({ }^{\circ} \mathrm{C} / \mathrm{min}\right)$ & 5 & 12.5 & 20 \\
$\mathrm{CO}_{2}$ flow rate $(\mathrm{mL} / \mathrm{min})$ & 80 & 140 & 200 \\
Activation time $(\mathrm{min})$ & 30 & 105 & 180 \\
\hline
\end{tabular}

Table 4. Test condition and results of oil yield $\left(\eta_{0}\right)$ from the pyrolysis process.

\begin{tabular}{cccc}
\hline $\begin{array}{c}\text { Temperature } \\
\left({ }^{\circ} \mathrm{C}\right)\end{array}$ & $\begin{array}{c}\text { Heating rate } \\
\left({ }^{\circ} \mathrm{C} / \mathrm{min}\right)\end{array}$ & $\begin{array}{c}\text { Pressure } \\
(\mathrm{mmHg})\end{array}$ & $\begin{array}{c}\eta_{\mathrm{o}} \\
(\%)\end{array}$ \\
\hline-1 & -1 & -1 & 44.0 \\
-1 & -1 & -1 & 45.6 \\
+1 & -1 & -1 & 53.0 \\
+1 & -1 & -1 & 52.2 \\
-1 & +1 & -1 & 50.5 \\
-1 & +1 & -1 & 48.6 \\
+1 & +1 & -1 & 51.7 \\
+1 & +1 & -1 & 51.4 \\
-1 & -1 & +1 & 35.0 \\
-1 & -1 & +1 & 30.3 \\
+1 & -1 & +1 & 42.0 \\
+1 & -1 & +1 & 46.8 \\
-1 & +1 & +1 & 44.6 \\
-1 & +1 & +1 & 41.7 \\
+1 & +1 & +1 & 50.7 \\
+1 & +1 & +1 & 51.4 \\
\hline
\end{tabular}

Table 5. Statistical treatment of oil yield from the pyrolysis process.

\begin{tabular}{|c|c|c|c|c|}
\hline & \multirow[t]{2}{*}{ Effect } & \multirow{2}{*}{$\begin{array}{l}\text { Std. } \\
\text { error }\end{array}$} & \multicolumn{2}{|c|}{ Confidence interval } \\
\hline & & & $-95 \%$ & $+95 \%$ \\
\hline \multicolumn{5}{|c|}{ Principal factor } \\
\hline 1 (Temperature) & 8.23 & 1.04 & 5.84 & 1.62 \\
\hline 2 (Heating Rate) & 4.34 & 1.04 & 1.95 & 6.72 \\
\hline 3 (Pressure) & -7.70 & 1.04 & -10.08 & -5.31 \\
\hline \multicolumn{5}{|c|}{ Interaction of two factors } \\
\hline 12 & -1.52 & 1.04 & -3.91 & 0.87 \\
\hline 13 & 3.34 & 1.04 & 0.95 & 5.73 \\
\hline 23 & -2.50 & 1.04 & 0.11 & 4.88 \\
\hline \multicolumn{5}{|c|}{ Interaction of three factors } \\
\hline 123 & -1.37 & 1.04 & -1.02 & 3.76 \\
\hline
\end{tabular}

Table 6. Test conditions and results for activated carbon yield $\left(\eta_{\mathrm{ca}}\right)$ and specific surface area (SSA) obtained with the steam-activated process.

\begin{tabular}{|c|c|c|c|c|c|}
\hline Test & $\begin{array}{c}\text { Temperature } \\
\left({ }^{\circ} \mathrm{C}\right)\end{array}$ & $\begin{array}{l}\text { Activation time } \\
\text { (min) }\end{array}$ & $\begin{array}{c}\text { Steam Flow rate } \\
(\mathrm{mL} / \mathrm{min})\end{array}$ & $\begin{array}{l}\eta_{\mathrm{ca}} \\
(\%)\end{array}$ & $\begin{array}{c}\text { SSA } \\
\left(\mathrm{m}^{2} \cdot \mathrm{g}^{-1}\right)\end{array}$ \\
\hline S1 & -1 & -1 & -1 & 40.7 & 79 \\
\hline $\mathrm{S} 2$ & +1 & -1 & -1 & 38.5 & 98 \\
\hline S3 & -1 & +1 & -1 & 40.4 & 81 \\
\hline S4 & +1 & +1 & -1 & 35.8 & 195 \\
\hline S5 & -1 & -1 & +1 & 40.4 & 84 \\
\hline S6 & +1 & -1 & +1 & 37.7 & 126 \\
\hline S7 & -1 & +1 & +1 & 39.8 & 87 \\
\hline S8 & +1 & +1 & +1 & 34.8 & 212 \\
\hline S9 & 0 & 0 & 0 & 39.0 & 94 \\
\hline S10 & 0 & 0 & 0 & 39.1 & 96 \\
\hline S11 & 0 & 0 & 0 & 39.0 & 97 \\
\hline
\end{tabular}


variables, reaching $212 \mathrm{~m}^{2} \cdot \mathrm{g}^{-1}$. This condition therefore resulted in the lowest yield, for the higher the residence time and temperature, the more material is consumed. Table 7 lists statistically significant variables of the steam-activated process.

As can be seen in Table 7, all the variables and the interactions between temperature and activation time (12) and temperature and flow rate (13) are significant at a confidence level of 95\%. All results are positive, indicating that the higher the values of the variables (temperature, activation time and flow rate) the higher the specific surface area of the resulting activated carbon. Table 8 shows the operating conditions and the results obtained with $\mathrm{CO}_{2}$ activation.

Again, the values in Table 8 indicate that the highest specific surface area $\left(169 \mathrm{~m}^{2} \cdot \mathrm{g}^{-1}\right)$ was obtained with the highest variables except for the heating rate, which showed the lowest yield, although even this variable resulted in an interesting value (35\%) considering the cost of the feedstock. A comparison of these results against those obtained with steam reveals very similar values. Table 9 presents the statistical treatment of the yield from the $\mathrm{CO}_{2}$-activated process.

Table 7. Statistical treatment of specific surface area (SSA) resulting from the steam-activated process.

\begin{tabular}{|c|c|c|c|c|}
\hline & \multirow[t]{2}{*}{ Effect } & \multirow{2}{*}{$\begin{array}{l}\text { Std. } \\
\text { error }\end{array}$} & \multicolumn{2}{|c|}{ Confidence interval } \\
\hline & & & $-95 \%$ & $+95 \%$ \\
\hline \multicolumn{5}{|c|}{ Principal factor } \\
\hline 1 (Temperature) & 74.77 & 1.72 & 67.35 & 82.19 \\
\hline 2 (Activation Time) & 46.79 & 1.72 & 39.37 & 54.21 \\
\hline 3 (Steam flow rate) & 13.98 & 1.72 & 6.56 & 21.40 \\
\hline \multicolumn{5}{|c|}{ Interaction of two factors } \\
\hline 12 & 44.59 & 1.72 & 37.18 & 52.00 \\
\hline 13 & 8.82 & 1.72 & 1.40 & 16.24 \\
\hline 23 & -2.27 & 1.72 & -9.69 & 5.14 \\
\hline \multicolumn{5}{|c|}{ Interaction of three factors } \\
\hline 123 & -3.22 & 1.72 & -10.64 & 4.20 \\
\hline
\end{tabular}

As can be seen in Table 9, all the variables, as well as the interactions between temperature and time (14), temperature, heating rate and flow rate (123), and temperature, flow rate and time (134), are statistically significant. The variable of temperature shows the lowest value. All the values are negative, indicating that the lower the variable the higher the yield of activated carbon. Table 10 presents statistical data on the specific surface area of the $\mathrm{CO}_{2}$-activated carbon.

An analysis of Table 10 leads to the conclusion that only the heating rate and the interactions between temperature and heating rate (12), and heating rate and time (24), are not statistically significant at a confidence limit of $95 \%$. Once more, the variable presenting the

Table 9. Statistical treatment of activated carbon yield from the $\mathrm{CO}_{2}$-activated process.

\begin{tabular}{|c|c|c|c|c|}
\hline & \multirow[t]{2}{*}{ Effect } & \multirow{2}{*}{$\begin{array}{l}\text { Std. } \\
\text { error }\end{array}$} & \multicolumn{2}{|c|}{ Confidence interval } \\
\hline & & & $-95 \%$ & $+95 \%$ \\
\hline \multicolumn{5}{|c|}{ Principal factor } \\
\hline 1 (Temperature) & -2.16 & 0.18 & -2.91 & -1.40 \\
\hline 2 (Heating Rate) & -1.23 & 0.18 & -1.99 & -0.48 \\
\hline 3 (Gas Flow Rate) & -1.58 & 0.18 & -2.34 & -0.83 \\
\hline 4 (Activation Time) & -1.57 & 0.18 & -2.32 & -0.81 \\
\hline \multicolumn{5}{|c|}{ Interaction of two factors } \\
\hline 12 & 0.71 & 0.18 & -0.05 & 1.46 \\
\hline 13 & -0.07 & 0.18 & -0.82 & 0.69 \\
\hline 14 & -2.41 & 0.18 & -3.16 & -1.65 \\
\hline 23 & -0.40 & 0.18 & -1.15 & 0.36 \\
\hline 24 & 0.69 & 0.18 & -0.06 & 1.45 \\
\hline 34 & 0.17 & 0.18 & -0.59 & 0.92 \\
\hline \multicolumn{5}{|c|}{ Interaction of three factors } \\
\hline 123 & 0.92 & 0.18 & 0.16 & 1.67 \\
\hline 124 & -0.44 & 0.18 & -1.20 & 0.31 \\
\hline 134 & -0.94 & 0.18 & -1.70 & -0.19 \\
\hline 234 & 0.41 & 0.18 & -0.35 & 1.16 \\
\hline
\end{tabular}

Table 8. Test conditions and results for activated carbon yield $\left(\eta_{\mathrm{ca}}\right)$ and specific surface area (SSA) obtained in the $\mathrm{CO}_{2}$-activated process.

\begin{tabular}{|c|c|c|c|c|c|c|}
\hline Test & $\begin{array}{c}\text { Temperature } \\
\left({ }^{\circ} \mathrm{C}\right)\end{array}$ & $\begin{array}{l}\text { Heating rate } \\
\left({ }^{\circ} \mathrm{C} / \mathrm{min}\right)\end{array}$ & $\begin{array}{c}\text { Gas flow rate } \\
(\mathrm{mL} / \mathrm{min})\end{array}$ & $\begin{array}{l}\text { Activation time } \\
(\min )\end{array}$ & $\begin{array}{l}\eta_{\mathrm{ca}} \\
(\%)\end{array}$ & $\begin{array}{c}\text { SSA } \\
\left(\mathrm{m}^{2} \cdot \mathrm{g}^{-1}\right)\end{array}$ \\
\hline $\mathrm{C} 1$ & -1 & -1 & -1 & -1 & 41.7 & 78 \\
\hline $\mathrm{C} 2$ & +1 & -1 & -1 & -1 & 41.5 & 79 \\
\hline C3 & -1 & +1 & -1 & -1 & 41.0 & 82 \\
\hline $\mathrm{C} 4$ & +1 & +1 & -1 & -1 & 39.9 & 84 \\
\hline C5 & -1 & -1 & +1 & -1 & 41.4 & 81 \\
\hline C6 & +1 & -1 & +1 & -1 & 39.8 & 90 \\
\hline C7 & +1 & +1 & +1 & -1 & 39.8 & 89 \\
\hline C8 & -1 & +1 & +1 & -1 & 36.0 & 81 \\
\hline C9 & -1 & -1 & -1 & +1 & 41.3 & 81 \\
\hline C10 & +1 & -1 & -1 & +1 & 37.8 & 98 \\
\hline C11 & -1 & +1 & -1 & +1 & 40.8 & 81 \\
\hline C12 & +1 & +1 & -1 & +1 & 37.2 & 117 \\
\hline C13 & +1 & -1 & +1 & +1 & 35.1 & 169 \\
\hline C14 & -1 & -1 & +1 & +1 & 41.2 & 84 \\
\hline C15 & +1 & +1 & +1 & +1 & 35.1 & 154 \\
\hline C16 & -1 & +1 & +1 & +1 & 40.1 & 84 \\
\hline C17 & 0 & 0 & 0 & 0 & 40.9 & 82 \\
\hline C18 & 0 & 0 & 0 & 0 & 40.2 & 85 \\
\hline C19 & 0 & 0 & 0 & 0 & 40.5 & 84 \\
\hline
\end{tabular}


Table 10. Statistical treatment of specific surface area obtained in the $\mathrm{CO}_{2}-$ activated process.

\begin{tabular}{|c|c|c|c|c|}
\hline & \multirow[t]{2}{*}{ Effect } & \multirow{2}{*}{$\begin{array}{l}\text { Std. } \\
\text { error }\end{array}$} & \multicolumn{2}{|c|}{ Confidence interval } \\
\hline & & & $-95 \%$ & $+95 \%$ \\
\hline \multicolumn{5}{|c|}{ Principal factor } \\
\hline 1 (Temperature) & 28.45 & 0.86 & 24.73 & 32.17 \\
\hline 2 (Heating Rate) & 1.69 & 0.86 & -2.03 & 5.41 \\
\hline 3 (Gas Flow Rate) & 16.40 & 0.86 & 12.68 & 20.11 \\
\hline 4 (Activation Time) & 25.37 & 0.86 & 21.65 & 29.09 \\
\hline \multicolumn{5}{|c|}{ Interaction of two factors } \\
\hline 12 & 0.62 & 0.86 & -3.10 & 4.34 \\
\hline 13 & 14.59 & 0.86 & 10.87 & 18.31 \\
\hline 14 & 23.48 & 0.86 & 19.76 & 27.20 \\
\hline 23 & -5.57 & 0.86 & -9.29 & -1.86 \\
\hline 24 & -0.59 & 0.86 & -4.31 & 3.12 \\
\hline 34 & 12.17 & 0.86 & 8.46 & 15.89 \\
\hline \multicolumn{5}{|c|}{ Interaction of three factors } \\
\hline 123 & -4.36 & 0.86 & -8.08 & -0.64 \\
\hline 124 & 0.50 & 0.86 & -3.21 & 4.22 \\
\hline $134 \mathrm{~s}$ & 10.97 & 0.86 & 7.25 & 14.69 \\
\hline 234 & -3.11 & 0.86 & -6.83 & 0.61 \\
\hline
\end{tabular}

strongest effect is temperature, with a positive value, indicating that the higher the temperature the larger the specific surface area.

Figure 2 shows isotherms obtained for four samples of scrap tire-derived carbon activated by two agents, i.e., steam $\left(\mathrm{S} 1: 80 \mathrm{~m}^{2} . \mathrm{g}^{-1}\right.$ and S8: $\left.212 \mathrm{~m}^{2} \cdot \mathrm{g}^{-1}\right)$ and $\mathrm{CO}_{2}\left(\mathrm{C} 13: 169 \mathrm{~m}^{2} \cdot \mathrm{g}^{-1}\right.$ and $\left.\mathrm{C} 1: 78 \mathrm{~m}^{2} \cdot \mathrm{g}^{-1}\right)$, which are the highest and lowest values of specific surface area for each activating agent.

Figure 2 indicates that all the isotherms are classified as type IV, ${ }^{12,13}$ which presents a linear region above 0.3 of relative pressure, indicating the occurrence of multiple layer adsorptions on the carbon surface. At a relative pressure exceeding 0.7, the capillary condensation in the meso- and macropores began changing the slope of the adsorption isotherm. Figure 2 also indicates that the isotherms present a type 1 hysteresis characterized by two almost parallel paths, which is typical of porous materials composed of rigid spherical particles of homogeneous size. The most suitable porous model to describe this situation is usually the cylindrical pore model, which is open at the two ends. Figure 3 shows the adsorption kinetics of four activated carbon samples: $\mathrm{C} 13, \mathrm{C} 1, \mathrm{~S} 1$ and $\mathrm{S} 8$.

Figure 3 indicates that the $\mathrm{CO}_{2}$-activated samples displayed longer equilibrium times than the steam-activated samples. This difference is attributed to the activation process, since the steam-activated samples produce activated carbons containing more micropores (smaller than $2 \mathrm{~nm}$ ) that are more easily saturated by the methylene blue molecule, which is larger than $2 \mathrm{~nm}$. The $\mathrm{CO}_{2}$-activated samples have more numerous mesopores (between $2 \mathrm{~nm}$ and $50 \mathrm{~nm}$ ) resulting from a strong oxidizing action, which increases the area available for adsorption. Figures 2 and 3 indicate that although sample S8 has a greater capacity for nitrogen adsorption than sample $\mathrm{C} 1$, both have the same capacity for methylene blue adsorption. This is ascribed to the fact that the nitrogen molecule is about the same size as the micropores, and therefore all the available surface area is used for adsorption, while the methylene blue adsorption occurs only in the available mesopores.

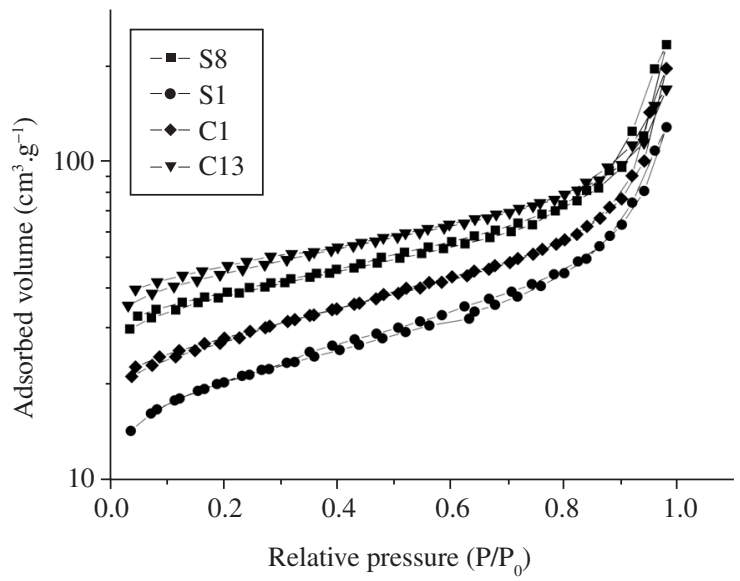

Figure 2. Adsorption/Desorption isotherms for nitrogen at $77 \mathrm{~K}$.

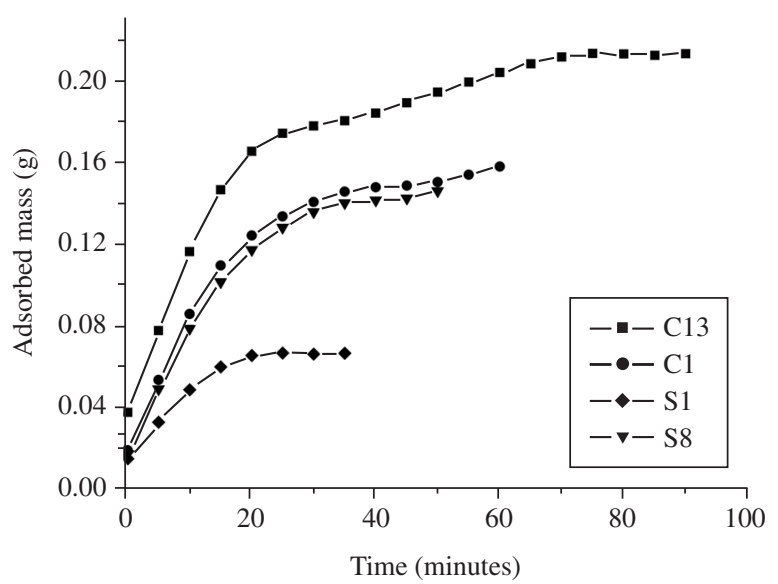

Figure 3. Adsorbed mass o methylene blue on samples of activated carbon.

\section{Conclusions}

In this study, fuel oil and activated carbon were produced from scrap tires. The activated carbon showed properties similar to that of the commercial product, with a surface area exceeding $200 \mathrm{~m}^{2} \cdot \mathrm{g}^{-1}$. The parameter exerting the strongest influence on the activation process was temperature, i.e., the higher the temperature the larger the surface area of the activated carbon.

As for the pyrolysis process, the higher the temperature and the lower the pressure the higher the fuel oil yield. No information was obtained with respect to the heating value and the quality of the oil. Pyrolysis proved to be a feasible alternative to handle the problem of scrap tire disposal. The process yielded $46 \%$ of oil, $40 \%$ of activated carbon and $14 \%$ of gases, which can be used as a source of heat in the pyrolysis process.

\section{References}

1. Díez C, Sánchez ME, Haxaire P, Martínez O, Morán A. Pyrolysis of tires: Acomparison of the results from a fixed-bed laboratory reactor and a pilot plant (rotary reactor). Journal of Analytical and Applied Pyrolysis 2005; 74(1-2):254-258 
2. Cunliffe AM, Williams PT. Composition of oils derived from the batch pyrolysis of tyres. Journal of Analytical and Applied Pyrolysis 1998; 44(2):131-152

3. Zabaniotou AA, Stavropoulos G. Pyrolysis of used tires and residual char utilization. Journal of Analytical and Applied Pyrolysis 2003; 70(2):711-722

4. Díez C, Martinez O, Calvi LF, Cara J, Morán A. Pyrolysis of tyres. Influence of the final temperature of the process on emissions and the calorific value of the products recovered. Waste Management 2004; 24(5):463-469.

5. Mui ELK, Ko DCK, McKay G. Production of active carbons from waste tyres - a review. Carbon 2004; 42(14):2789-2805.

6. Rodriguez IM, Laresgoiti MF, Cabrero MA, Torres A, Chomón MJ, Caballero B. Pyrolysis of scrap tyres. Fuel Processing Technology 2001; 72:9-22.

7. Laresgoiti MF, Caballero BM, Marco I, Torres A, Cabrero MA, Chomón MJ. Characterization of the Liquid Products Obtained on Tyre Pyrolysis. Journal of Analytical and Applied Pyrolysis 2001; 71(2):917-934.
8. Miguel GS, Fowler GD, Sollars CJ. A study of the characteristics of activated carbons produced by steam and dioxide activation of waste tyre rubber. Carbon 2003; 41(5):1009-10016.

9. Cui H, Yang J, Liu Z. Thermogravimetric analysis of two Chinese used tires. Termochimica Acta 1999; 333(2):173-175.

10. Roy C, Chaala A, Darmstadt H. The Vacuum pyrolysis of used tires endused for oil and carbon black products. Journal of Analytical and Applied Pyrolysis 1999; 51(1-2):201-221.

11. Roy C, Darmstadt H, Benallal B, Amen-Chen C. Characterization of naphtha and carbon black obtained by vacuum pyrolysis of polyisoprene rubber. Fuel processing Technology 1997; 50(1):87-103.

12. Dubinin MM. Porous Structure and Adsorption Properties of Activated Carbons. In Chemistry and Physics of Carbon/A Series of Advances. Marcel Dekker Inc.; 1965. p. 51-120.

13. Everett DH. Manual of Symbols and Terminology for Physicochemical Quantities and Units, Appendix II: Definitions, Terminology and Symbols in Colloid and Surface Chemistry. Pure and Applied Chemistry 1972; 31(4):577-638. 
